\title{
The Politics of Finance in Developing Countries
}


A volume in the series

Cornell Studies in Political Economy

Edited by Peter J. Katzenstein

A full list of titles in the series appears at the end of the book. 


\section{The Politics of Finance in Developing Countries}

Edited by

Stephan Haggard,

Chung H. Lee, and Sylvia Maxfield

Cornell University Press

Ithaca and London 


\section{Copyright (C) 1993 by Cornell University}

All rights reserved. Except for brief quotations in a review, this book, or parts thereof, must not be reproduced in any form without permission in writing from the publisher. For information, address Cornell University Press, Sage House, $5^{12}$ East State Street, Ithaca, New York $1485^{\circ}$

First published 1993 by Cornell University Press.

International Standard Book Number o-8014-2892-o (cloth) International Standard Book Number o-8o $14-81$ 30-9 (paper) Library of Congress Catalog Card Number 93-28589

Librarians: Library of Congress cataloging information appears on the last page of the book.

(2) The paper in this book meets the minimum requirements of the American National Standard for Information Sciences-Permanence of Paper for Printed Library Materials, ANS! Z39.48-1984. 